\title{
Antimicrobial evaluation, acute and subchronic toxicity studies of Leone Bitters, a Nigerian polyherbal formulation, in rodents. ${ }^{1}$ Ogbonnia S. O, ${ }^{*}$ Mbaka G. O, ${ }^{3}$ Igbokwe N. H, ${ }^{4}$ Anyika E. N, ${ }^{5}$ Alli P and ${ }^{6}$ Nwakakwa N ${ }^{1}$ Department of Pharmacognosy, University of Lagos, Nigeria. \\ $2^{*}$ Department of Anatomy, Olabisi Onabanjo University. Ago-Iwoye, Ogun State, Nigeria. ${ }^{3}$ Department of Pharmaceutical Technology and Pharmaceutical Microbiology, University of Lagos, Nigeria. \\ ${ }^{4}$ Department of Clinical Pharmacy and Biopharmacy, University of Lagos, Nigeria. ${ }^{5}$ Department of Anatomy, Olabibsi Onabanjo University, Ago-Iwoye, Ogun State, Nigeria. \\ ${ }^{6}$ Federal College of Complementary and Alternative Medicine, Ketu, Lagos, Nigeria. GSM: 234-805-8426729
}

\begin{abstract}
This study evaluated acute and sub-chronic toxicities in rodents and microbial purity of a polyherbal preparation, Leon Bitters, prepared with Gongronema latifolia (climbing stem), Cocos nucifera (coconut) roots and Parinari curatellifolia seeds. Microbial purity was evaluated on some bacterial and fungal organisms using appropriate diagnostic media. Toxicity of the polyherbal preparation was evaluated in Swiss albino mice by administering to the animals oral graded doses of the lyophilized drug in the ranges of $1.0 \mathrm{~g} / \mathrm{kg}$ to $20.0 \mathrm{~g} / \mathrm{kg}$ body weight and observed continuously for the first $4 \mathrm{~h}$ and hourly for the next $12 \mathrm{~h}$, then 6 hourly for $56 \mathrm{~h}(72 \mathrm{~h}$, acute toxicity). Wistar rats were also fed with different doses of the lyophilized drug for 30 days and the effects of the drug on some tissues - heart, liver, kidney and testes - were microscopically examined. Also the effects on the biochemical and haematological parameters were evaluated (sub-chronic toxicity model). No zone of inhibition was observed on either the bacterial culture media or the fungal culture media. The median acute toxicity value $\left(\mathrm{LD}_{50}\right)$ of the polyherbal medicine was determined to be $7.2 \mathrm{~g} / \mathrm{kg}$ body weight. No significant increase in the body weight was observed in the groups treated with the drug compared to the control. There was significant increase $(p \leq 0.05)$ in creatinine level while aspartate aminotransferases (AST) and alanine aminotransferases (ALT) showed no appreciable increase. The drug significantly reduced $(p \leq 0.05)$ triglyceride $(T G)$ level while low density lipoprotein ( $L D L)$-cholesterol level was not altered, but led to increase in high density lipoprotein (HDL)-cholesterol in the treated groups compared to the control. There was no significant change in the mean corpuscular haemoglobin $(\mathrm{MCH})$, mean corpuscular volume (MCV) and mean corpuscular haemoglobin concentration (MCHC) in all the treated animals compared to the control. The study showed that the drug exhibited hypolipidemic activity and good reducing effects on cardiovascular factors. However, a long term use may be harmful to the testes, a male reproductive organ.
\end{abstract}

Keywords: Microbial purity, acute toxicity, sub-chronic toxicity, Gongronema latifolia, Cocos nucifera, Parinari curatellifolia

\section{INTRODUCTION}

The discovery that compounds derived from plants could act as potential therapeutic weapons against various human, animal and even plant diseases, in addition to their food and nutritional values, has made plants invaluable and indispensable to human and animal lives (Ogbonnia et al., 2008). Plants with therapeutic activities are known as medicinal plants and remain the main source of the active drugs from natural sources. Plant derived medicine is popularly known as herbal or phytomedicine. Herbal medicine is renowned as the most common form of alternative medicine and is used by about $60 \%$ of the world population both in the developing countries and in the developed countries where modern medicines are predominantly used (Rickert et al., 1999; Ogbonnia et al., 2008).

The use of herbal medicines by the traditional practitioners for treatment of diseases remains the main stay of health care system and is gaining increasing popularity especially among the rural populace in the developing countries. Its rising popularity could be attributed to its advantages of being efficacious and also a cheap source of medical care. There is also growing disillusion with modern medicine coupled with the misconception that herbal 
products being natural may be devoid of adverse and toxic effects associated with convectional and allopathic medicines. Herbal preparations assumed to be safe could be contaminated with microbial and foreign materials such as heavy metals, pesticide residues or even aflatoxins due to the unhygienic way many are produced. The presence of any of the possible contaminants is a potential health risk to a vast population that depends on herbal medicine for their health care need. Increased morbidity and mortality associated with the use of herbs or the so called traditional medicines has raised universal attention in the last few years (Bandaranayake, 2006). Upon exposure, the clinical toxicity may vary from mild to severe and even life threatening making the safety and toxicity evaluations of these preparations imperative.

Phytomedicine is most often a 'polyherbal formulation prepared from mixtures of many plant parts obtained from various plant species and families and may contain multiple bioactive constituents that could be difficult to characterize. The bioactive principles in most herbal preparations are not always known and there could be possibilities of interaction with each other in solution. The quality as well as the safety criteria for herbal drugs may be based, therefore, on a clear scientific definition of the raw materials used for such preparations. Also herbal medicine may have multiple physiological activities and could be used in the treatment of a variety of disease conditions (Pieme et al., 2006). They may be administered in most disease conditions over a long period of time without proper dosage monitoring and consideration of toxic effects that might result from such prolonged usage. The danger associated with the potential toxicity of such therapy and other herbal therapies used over a long period of time demand that the practitioners be kept abreast of the reported incidence of renal and hepatic toxicity resulting from the ingestion of medicinal herbs (Tédong et al., 2007).

Leon Bitters is a popular polyherbal medicine used generally for well being, as an appetite stimulant and as a stomachic. It is prepared with Parinari curatellifolia Planch (Chrysobalanaceae) seeds, Cocos nucifera (Palmae) roots and Gongronema latifolia Benth (Asclepiadaceae) climbing stem. Parinari curatellifolia called "Ebere" by the Nigerian Yorubas is a valuable and cherished medicinal plant in which different parts of the plant are widely used by the traditional herbalists in the treatment of various diseases. It may be used alone or in combination with other herbs locally in the treatment of diabetes and other diseases and has been evaluated for its antidiabetic activities (Ogbonnia et al., 2009). Coconut tree called "Aki oyibo" or "English nut" by the Igbos of Eastern Nigeria is also a highly valued and cherished economic plant. The nuts' inner part is edible and a source of oil employed in cooking and also in cosmetics while Gongronema latifolia (Utazi) is very popular amongst the Igbos and is used as condiment especially after child birth and has been evaluated for its antioxidant activity (Odukoya et al., 2007). The combination therapy is more common, since most traditional medical practitioners believe that a combination of many plant products would create the desired synergistic effect.

The aim of this study was to evaluate the safety of a polyherbal preparation, Leons Bitters, by investigating its microbial purity, and carrying out the acute and sub-chronic toxicity studies in rodents. Sub-chronic toxicity evaluation is required to establish potential adverse effects of this highly valuable polyherbal medicine that is now widely consumed for its physiological benefits.

\section{MATERIALS AND METHODS}

The polyherbal medicine in powder form was conceded by Herbal Fountain Nigeria Ltd of No 16 Light Real Street, Alagbado Lagos, Nigeria and was prepared with dried $P$. curatellifolia seeds, $C$. nucifera (coconut) roots and G. latifolia (Utazi) climbing stem.

Preparation of the medicine: Dried climbing stem of $G$. latifolia, roots of $C$. nucifera and $P$. curatellifolia seeds were respectively powdered to coarse particles. A batch size of $50 \mathrm{~L}$ was prepared by boiling 8 kilograms of thoroughly mixed powders at the ratio of $4: 1: 3$ with $30 \mathrm{~L}$ of previously boiled and cooled purified water in a $50 \mathrm{~L}$ stainless container for 45-60 min and allowed to decoct for $24 \mathrm{hr}$. This was filtered through a muslim cloth (previously soaked with $75 \%$ ethanol overnight) into a $75 \mathrm{~L}$ calibrated stainless container with dispensing tap previously washed with copious amount of $75 \%$ ethanol. The volume was made up to $50 \mathrm{~L}$ mark with sterile water.

The polyherbal drug, a light yellowish liquid, was stored in an amber plastic bottle of $200 \mathrm{ml}$. The prescribed dose for human is two table spoonfuls (20 $\mathrm{ml}$ ) (equivalent to $0.286 \mathrm{ml} / \mathrm{kg}$ for an average man of $70 \mathrm{~kg}$ ) three times a day (60 ml/day). For acute and sub chronic studies, $500 \mathrm{ml}$ of the preparation was subjected to further filtration using Whatman's no 4 filter and the resulting $485 \mathrm{ml}$ filtrate was subsequently freeze dried to $34.7 \mathrm{~g}$ gel which was 
stored in an air tight container in a fridge until it was needed.

Determination of microbial purity: The microbial load of the preparation was determined using the standard plate method (Fontana et al., 2004). Various diagnostic media - Tryptone Soy Agar (TSA), Salmonella-Shigella Agar (SSA), Eosin Methylene Blue Agar (EMBA), MacConkey Agar (MAC), Nutrient Agar (NA), Manital Salt Agar (MSA), Sabouraud Dextrose Agar (SDA) - were used to culture the test product. Each of the media was prepared according to manufacturers' instruction and sterilized at $121{ }^{\circ} \mathrm{C}$ for 15 minutes.

Three fold serial dilutions $\left(10^{-1}, 10^{-2}\right.$ and $\left.10^{-3}\right)$ were made using sterile water and $1 \mathrm{ml}$ each of the dilutions seeded in $25 \mathrm{ml}$ each of the sterile culture media. The media were allowed to cool to $45{ }^{\circ} \mathrm{C}$, swirled and left to solidify. The bacterial media were incubated at $37{ }^{\circ} \mathrm{C}$ for 3 days while the fungal medium (SDA culture) was incubated at $25{ }^{\circ} \mathrm{C}$ for 7 days. They were examined 24 hourly during this period for the colonies and the results recorded (Table 1).

Assay of antimicrobial activity: The antimicrobial activity of the preparation was investigated using the cup diffusion method on nutrient agar (NA) for bacterial organisms and Sabouraud Dextrose Agar (SDA) for fungal organisms (Raghavendra, 2006).

$10^{6} \mathrm{cfu} / \mathrm{ml}$ of the overnight clinical cultures of Escherichia coli, Pseudomonas aeruginosa, Klebsiella specie, Shigella specie was seeded in 25 $\mathrm{ml}$ nutrient agar respectively while Candida albicans was seeded in Sabouraud Dextrose Agar. Wells were bored in each of the culture media using a sterile 12 $\mathrm{mm}$ cork borer and various dilutions $(100 \%, 50 \%$, $25 \%$ and $12.5 \%$ ) of the test material were prepared using sterile water. $0.5 \mathrm{ml}$ of each dilution was respectively seeded in wells made in inoculated plates with a blank well in each of the plates seeded with $0.5 \mathrm{ml}$ sterile water to serve as a control standard. The cultures were incubated for 24 hours and observations were made for zones of incubation (NCCLS, 1997).

Animals: Swiss mice $(20-25 \mathrm{~g})$ and Wistar rats $(160 \pm 20 \mathrm{~g})$ of either sex obtained from the Laboratory animal Center, College of Medicine, University of Lagos, Idi-Araba were kept under standard environmental condition of $12 / 12 \mathrm{hr}$ light/dark cycle. They were housed in polypropylene cages ( 5 animals per cage) and were maintained on mouse chow (Feeds Nigeria Ltd) and provided with water ad libitum. They were allowed to acclimatize for seven days to the laboratory conditions before the experiment.

Acute toxicity study: The toxicity study was carried out using thirty five (35) male and female Swiss albino mice. The animals were randomly distributed into one control group and six treated groups, containing five animals per group. After the overnight fasting, the control group received $0.3 \mathrm{~mL}$ of Tween $80(2 \%)$ solution orally. The doses $1.0,2.5,5.0,10.0$, 15.0 and $20.0 \mathrm{~g} / \mathrm{kg}$ were respectively administered orally to the groups from $80 \%(w / v)$ solution of the gel which was prepared by dispersing $16 \mathrm{~g}$ of the gel with $7 \mathrm{~mL}$ Tween $80(2 \%)$ solution in a $100 \mathrm{ml}$ beaker and transferred to a $20 \mathrm{~mL}$ volumetric flask. The beaker was thoroughly rinsed with the Tween solution; the content added to the volumetric flask and the volume made to mark with the Tween solution. The animals were observed continuously for the first 4 hours and then for each hour for the next 12 hours, followed by 6 hourly intervals for the next 56 hours (72 hrs observations) to observe any death or changes in general behavior and other physiological activities behavior and other physiological activities (Shah et al., 1997; Bürger et al., 2005)

Subchronic: Male and female Wistar rats weighing $160 \mathrm{~g} \pm 20 \mathrm{~g}$ were used. They were allowed to acclimatize to the laboratory conditions for seven days. The animals were maintained on standard animal feeds and provided with water ad libitum. The animals were weighed and divided into four groups of five animals each. After fasting the rats overnight the control group received a dose of $0.5 \mathrm{ml}$ of $2 \%$ Tween 80 solution orally once a day for 30 days. The three treated groups respectively received the following doses: 100, 250 and $500 \mathrm{mg} / \mathrm{kg}$ body weight of the gel orally once a day for 30 days (Pieme et al., 2006; Joshi et al., 2007; Mythilypriya el al., 2007). The gel suspension $(12 \% \mathrm{w} / \mathrm{v})$ was prepared by dispersing the gel $(12 \mathrm{~g})$ with $45 \mathrm{ml}$ of Tween $80(2 \%)$ solution in a beaker, and transferred to a $100 \mathrm{ml}$ volumetric flask. Then the beaker was rinsed with the solution and the content transferred to the volumetric flask and volume made to mark with the Tween solution. The animals were weighed every five days, from the start of the treatment, to note any weight variation. At the end of the experiment, the animals were starved overnight. On the 31 st day, they were made unconscious by cervical dislodgement and blood was collected via cardiac puncture in two tubes: one with EDTA for analysis of haematological parameters and 
the blood chemistry and the other with heparin to separate plasma for biochemical estimations. The heparinized blood was centrifuged within $5 \mathrm{~min}$ of collection at $4000 \mathrm{~g}$ for $10 \mathrm{~min}$ to obtain plasma, which was analyzed for total cholesterol, total triglyceride, and HDL-cholesterol levels by modified enzymatic procedures from Sigma Diagnostics (Wasan et al., 2001). LDL-cholesterol levels were calculated using Friedwald equation (Crook, 2007). Plasma was analyzed for Alanine aminotransferase (ALT), aspartate aminotransferase (AST), and creatinine by standard enzymatic assay methods (Sushruta et al., 2006). Plasma glucose contents and protein contents were determined using enzymatic spectroscopic methods (Hussain and Eshrat, 2002). Haematocrit was estimated using the method as described by Ekaidem et al., (2005). Haematocrit tubes were filled with whole blood to the mark by capillary action and the bottom of the tubes sealed with plasticide and centrifuged for 4-5 minutes using haematocrit centrifuge. The percentage cell volume was read by sliding the tube along a "critocap" chart until the meniscus of the plasma intersected the 100 $\%$ line. Haemoglobin contents were determined using Cyanmethaemoglobin (Drabkin) method (Ekaidem et al., 2005).

Statistical analysis: Significant differences were determined using a Student's t-test. Differences were considered significant if $p<0.05$. All data were expressed as mean \pm standard error of the mean.

\section{RESULTS}

Determination of microbial purity: There was no microbial growth observed in the first $24 \mathrm{hr}$ in both Table 1: Microbial Purity test of the polyherbal preparation

\begin{tabular}{|c|c|c|c|c|c|}
\hline Media & Dilution & $24 \mathrm{hr}$ & $48 \mathrm{hr}$ & $72 \mathrm{hr}$ & $6^{\text {th }}$ and $7^{\text {th }}$ Day \\
\hline \multirow[t]{2}{*}{ TSA } & $1 / 10$ & NG & NG & 1 & \\
\hline & $1 / 100$ & NG & NG & 1 & \\
\hline \multirow[t]{2}{*}{ SSA } & $1 / 10$ & NG & NG & NG & \\
\hline & $1 / 100$ & NG & NG & NG & \\
\hline \multirow[t]{2}{*}{ EMBA } & $1 / 10$ & NG & NG & NG & \\
\hline & $1 / 100$ & NG & NG & NG & \\
\hline \multirow[t]{2}{*}{ MAC } & $1 / 10$ & NG & NG & 1 & \\
\hline & $1 / 100$ & NG & NG & 1 & \\
\hline \multirow[t]{2}{*}{ NA } & $1 / 10$ & NG & 1 & 1 & \\
\hline & $1 / 100$ & NG & NG & 1 & \\
\hline \multirow[t]{2}{*}{ MSA } & $1 / 10$ & NG & NG & NG & \\
\hline & $1 / 100$ & NG & NG & NG & \\
\hline \multirow[t]{2}{*}{ SDA } & & NG & NG & & \\
\hline & $1 / 10$ & NG & NG & 1 & 1 \\
\hline
\end{tabular}

NG: No growth bacterial and fungal media. After $48 \mathrm{hrs}$ the nutrient agar media showed $1 \times 10^{1}$ colonies of Bacilus subtilis. In 72 hr, Tryptone Soy Agar and MacConkey agar cultures showed $1 \times 10^{2}$ colonies of Bacilus subtilis respectively while the microbial load of nutrient agar increased to $1 \times 10^{2}$ colonies. The Sabouraud Dextrose Agar showed only $1 \times 10^{1}$ colonies of Cladosporum specie on the $6^{\text {th }}$ and the $7^{\text {th }}$ day of incubation.

Antimicrobial activity assay: No zone of inhibition was observed on either the bacterial culture media or the fungal culture media

Acute toxicity test: The acute toxicity study (Table 1) recorded $80 \%$ death for all the animals that received $20.0 \mathrm{~g} / \mathrm{kg}$ bwt of the extract and $42.8 \%$ and $14.3 \%$ for animals that received $15.0 \mathrm{~g}$ and 10.0 $\mathrm{g}$ respectively, while there was no death in the animals that received $5.0 \mathrm{~g} / \mathrm{kg}$ bwt and less. The median acute toxicity $\left(\mathrm{LD}_{50}\right)$ of the extract was determined to be $7.2 \mathrm{~g} / \mathrm{kg}$ body weight.

Variation of weights: The effect of the drug on the body weights of the control and treated animals is shown in Table 2 and the percentage increase in the weight of the treated animals compared with the control is shown in Figure 1. Generally, there was insignificant $(p \geq 0.05)$ increase in the body weights of the treated animals compared to the control. A drop in body weight was observed in the all the treated animals in the first 5 days of the treatment. From day 10 the body weights increased continually to the end of the experiment. 
Agric. Biol. J. N. Am., 2010, 1(3): 366-376

Table 2: Acute toxicity of the polyherbal medicine in mice

\begin{tabular}{lccc}
$\begin{array}{l}\text { Doses of } \\
\text { Drug g/kg }\end{array}$ & $\begin{array}{c}\text { Number of } \\
\text { animals }\end{array}$ & $\begin{array}{c}\text { Number of } \\
\text { animals dead }\end{array}$ & $\begin{array}{c}\text { \% Cumulative } \\
\text { death }\end{array}$ \\
\hline 0.5 & 0 & 0 & 0 \\
1.0 & 5 & 0 & 0 \\
2.5 & 5 & 0 & 0 \\
5.0 & 5 & 0 & 0 \\
10.0 & 5 & 1 & 14.3 \\
15.0 & 5 & 2 & 42.8 \\
20.0 & 5 & 4 & 100.0 \\
\hline Co
\end{tabular}

Control group received orally $0.3 \mathrm{ml}$ each of normal saline

Histological studies: Figure II shows the histological studies of the effects of the phytomedicine on some organs. The hepatic tissue of the control $\left(A_{1}\right)$ showed the portal trait with lobular formation. The hepatocytes radially arranged were clearly interspaced by hepatic sinusoids. The animals $\left(A_{2}\right)$ treated with $500 \mathrm{mg} / \mathrm{kg}$ bwt, showed no pathologic changes in morphology and arrangement of hepatic cells.

The kidney of the control showed cortical area of renal tissue with glomerular apparatus $\left(B_{1}\right)$ forming a rounded mass and separated from the surrounding structures by Bowman's space. The animals $\left(B_{2}\right)$ treated with $500 \mathrm{mg} / \mathrm{kg}$ bwt showed no structural changes. In the normal testis $\left(C_{1}\right)$, the seminiferous tubules cut at different planes showed distinct boundary separated by interstitial spaces. The wall of the seminiferous tubules showed thick epithelium. Close to the base of the epithelium were the differentiating spermatogonia while spermatids and spermatocytes formed a cluster within the lumina. In the treated animals $\mathrm{C}_{2}$, depletion in cell mass occurred. Cross sections showed thin basal layer and scanty spermatocytes interspaced in a wide lumina. The cardiac muscle of the control animals $\left(D_{1}\right)$ in the longitudinal section showed the muscle fibres forming a branched network while the cardiac muscle of the treated animals $\left(D_{2}\right)$ showed no indication of cellular lesion or distortion.

Biochemical parameters: Table 3 is a summary of the results of the effects of the drug on the biochemical parameters. The plasma protein showed no marked increment while significant rise $(p<0.05)$ in creatinine level were observed only in animals treated with highest dose of the drug compared with the control. There was no significant increase in AST and ALT levels in all the treated animals compared with the control. However, significant increase $(p<$ 0.05) in the plasma total cholesterol (TC) was observed in the groups that received the two highest dose of polyherbal drug. Decrease in triglyceride (TG) occurred while no significant changes in the LDL-cholesterol levels were observed. On the other hand, significant increase $(p<0.05)$ in HDLcholesterol levels occurred. The total bilirubin, urea and albumin of all the treated groups showed no changes compared to the control while significant changes in the level of alkaline phosphate was observed only in the group treated with highest dose of the drug.

Haematological studies: The effects of the drug on the red blood cells (RBC) components and white blood cell differentials were presented in Tables 4 and 5 respectively. Significant increases $(p<0.05)$ were observed in the haemoglobin content and RBC in all the groups compared to the control while significant changes in white blood cells (WBC) and packed cell volume (PCV) were only noticeable in the group that received $500 \mathrm{mg} / \mathrm{kg}$ bwt. There was no significant change in the mean corpuscular haemoglobin $(\mathrm{MCH})$, mean corpuscular volume (MCV) and mean corpuscular haemoglobin concentration (MCHC) and calcium level in all the treated animals compared to the control, while a significant increase $(p<0.05)$ in the level of phosphorus was observed only in the animals treated with $500 \mathrm{mg} / \mathrm{kg}$ bwt of the drug. Significant increase $(p<0.05)$ in the level of lymphocyte, neutrophil and platelet was respectively observed in all the treated animals compared to the control while there was no significant increase in the monocytes level.

The effects of the polyherbal medicine on the weight variation of the organs of the control and treated animals were presented in Table 6 . There were no significant changes observed in the weights of the organs of the control and the animals treated with various doses but significant increase $(p<0.05)$ was observed in the heart and kidney of the group treated with $500 \mathrm{mg} / \mathrm{kg}$ bwt of the herbal drug. 
Agric. Biol. J. N. Am., 2010, 1(3): 366-376

Table 3: The effects of the phytomedicine on weight changes in the control and treated rats in the subchronic toxicity study

\begin{tabular}{|c|c|c|c|c|c|c|c|}
\hline Group & Day 1 & Day 5 & Day 10 & Day 15 & Day 20 & DAY 25 & DAY 30 \\
\hline $\begin{array}{l}\text { Control } \\
100 \mathrm{mg} / \mathrm{kg} \\
250 \mathrm{mg} / \mathrm{kg} \\
500 \mathrm{mg} / \mathrm{kg}\end{array}$ & $\begin{array}{l}171.0 \pm 2.2 \\
150.0 \pm 0.1 \\
150.0 \pm 0.3 \\
160.2 \pm 6.1\end{array}$ & $\begin{array}{l}172.1 \pm 1.8 \\
152.4 \pm 2.8 \\
150.2 \pm 1.5 \\
161.3 \pm 6.9^{* *}\end{array}$ & $\begin{array}{l}173.5 \pm 1.1 \\
152.7 \pm 0.8^{* *} \\
148.0 \pm 7.5^{* *} \\
163.1 \pm 4.8\end{array}$ & $\begin{array}{l}175.6 \pm 2.5 \\
153.0 \pm 1.4 \\
148.2 \pm 6.3 \\
159.8 \pm 5.0\end{array}$ & $\begin{array}{l}178.8 \pm 2.7 \\
155.4 \pm 1.3^{*} \\
158.8 \pm 5.0^{*} \\
160.8 \pm 5.0\end{array}$ & $\begin{array}{l}179.8 \pm 2.2 \\
160.3 \pm 2.4^{*} \\
160.6 \pm 1.2^{*} \\
166.1 \pm 2.3^{*}\end{array}$ & $\begin{array}{l}180.1 \pm 2.2 \\
160.2 \pm 2.3^{*} \\
165.0 \pm 1.5^{*} \\
173.5 \pm 1.2^{*}\end{array}$ \\
\hline
\end{tabular}

Mean \pm sem, $(n=5){ }^{*} p<0.05 ;{ }^{* *} p<0.01$ vs control group.

Group I: Control rats received $0.5 \mathrm{ml}$ Tween $80(2 \%)$ solution: Group II: Rats administered with 100 mg/kg bwt of the extract: Group III: Rats administered with 250 $\mathrm{mg} / \mathrm{kg}$ bwt of the extract: Group III: Rats administered with $500 \mathrm{mg} / \mathrm{kg}$ bwt of the extract.

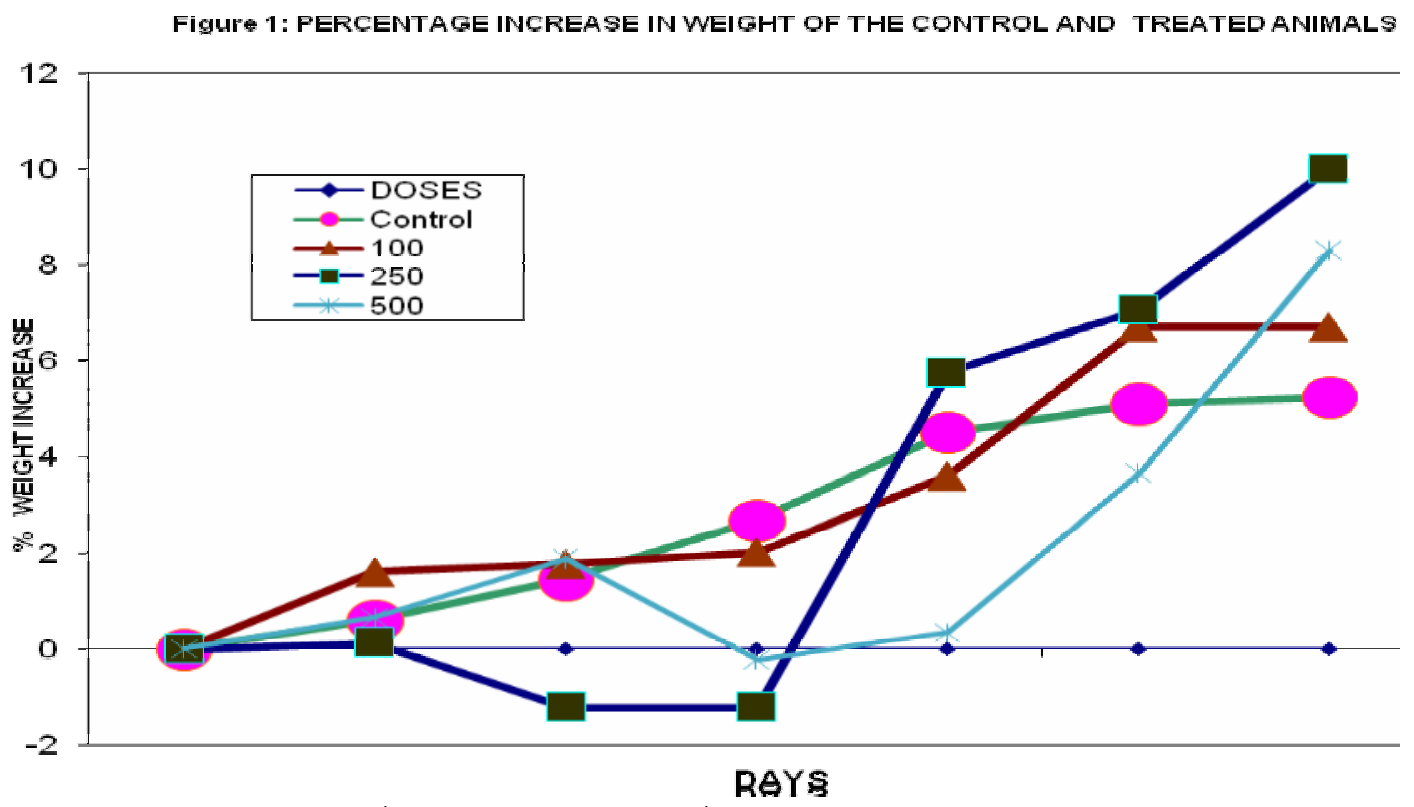

- control, $\triangle 100 \mathrm{mgkg}^{-1} \mathrm{bwt}, \mathbf{2} 250 \mathrm{mgkg}^{-1} \mathrm{bwt}, Ж 500100 \mathrm{~m}$ 
Agric. Biol. J. N. Am., 2010, 1(3): 366-376

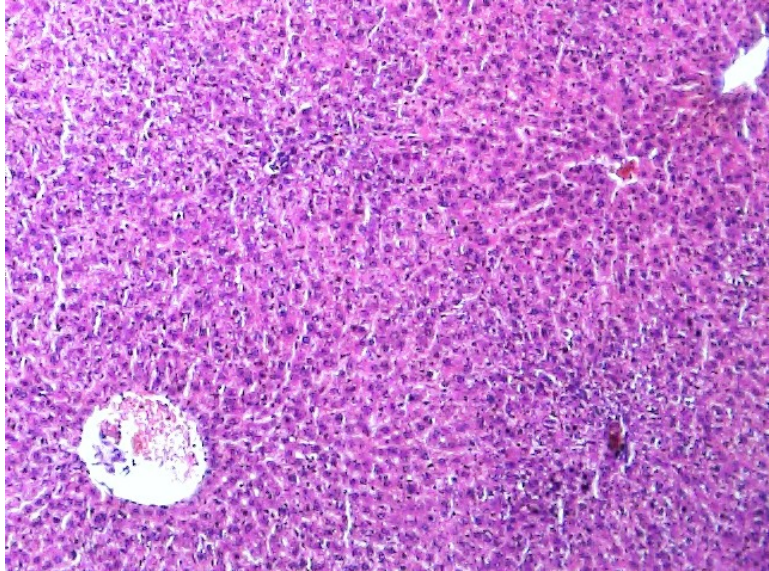

Fig. A1: The cross section of liver of the control group showing central vein and hepatocytes radially arranged ( $H$ and E stain). mag. $\times 100$.

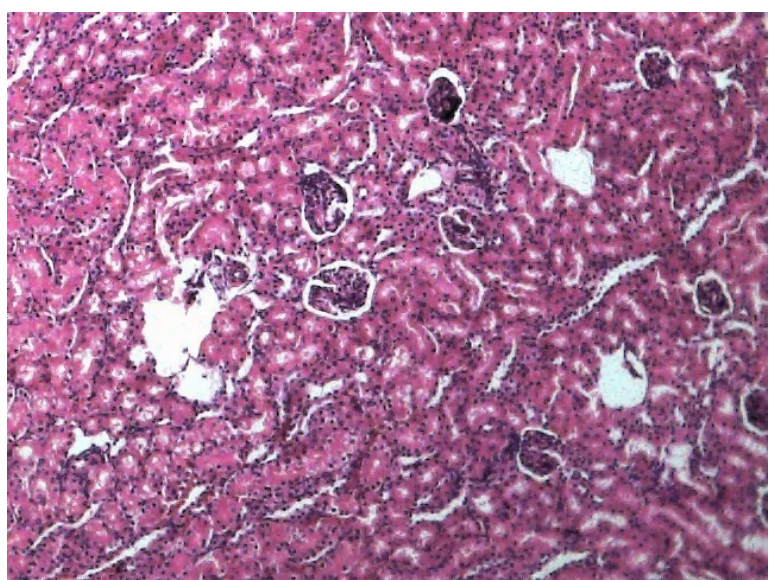

Fig. B1: The histology of a cross section of renal tissue of the control group showing renal corpuscles and Bowman's spaces ( $H$ and E stain) mag. $\times 100$.

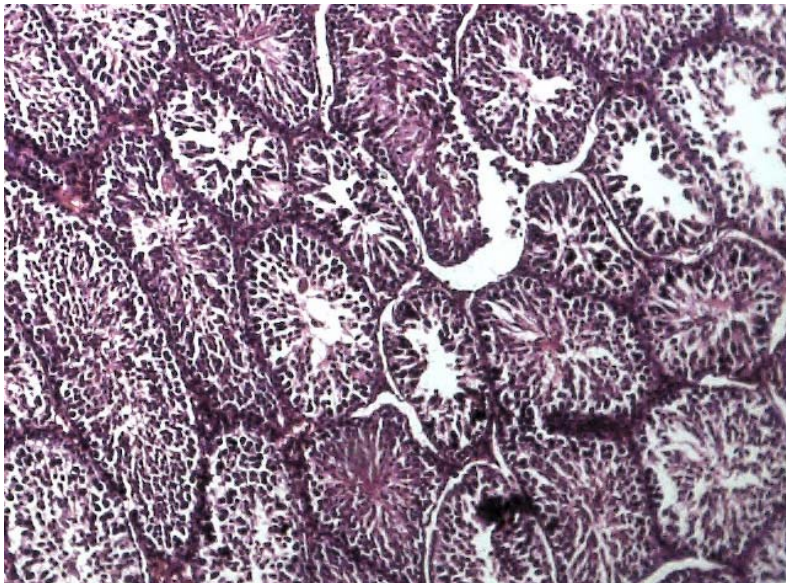

Fig. C1: The histology of testes of the control group showing cross sections of seminiferous tubules $(H$ and E stain). mag. $x 100$.

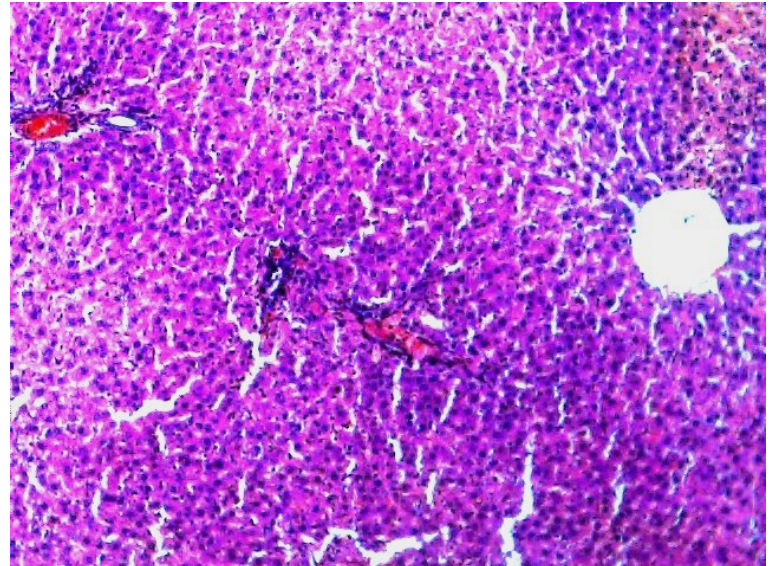

Fig. A2: The histology of the cross section of liver treated with $500 \mathrm{mg}$ of the polyherbal drug showing normal arrangement of hepatocytes (H and E stain). mag. $x 100$.

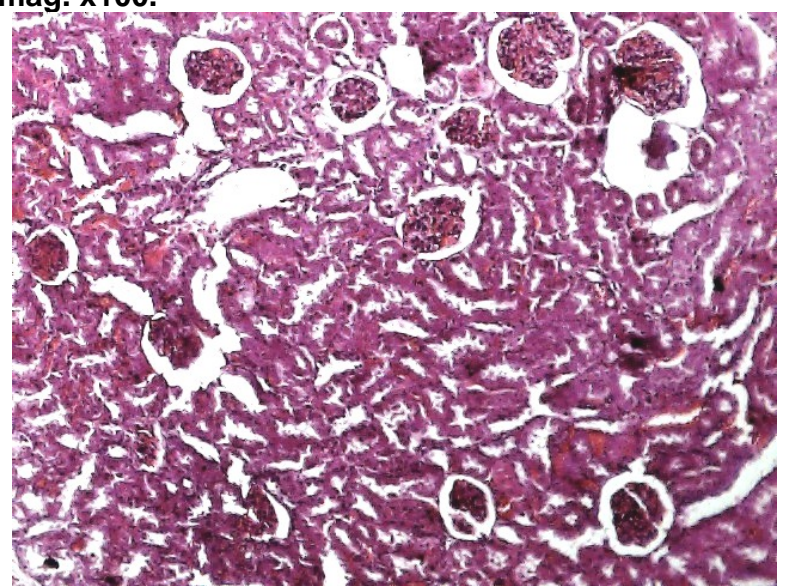

Fig. B2: The cross section of renal tissue treated with $500 \mathrm{mg}$ of the drug. No renal abnormality was observed ( $H$ and E stain) mag. x100

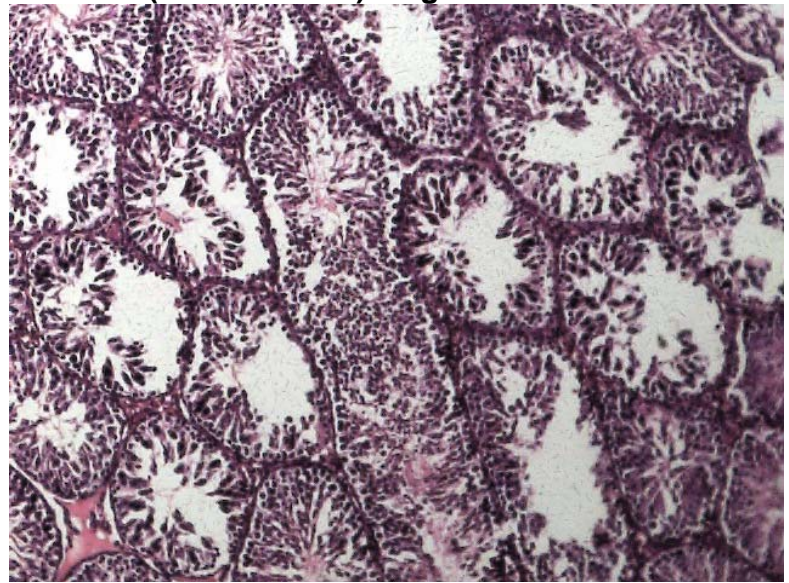

Fig. C2: The cross section of seminiferous tubules of testis treated with $500 \mathrm{mg}$ of the polyherbal drug showing wider lumina ( $\mathrm{H}$ and $\mathrm{E}$ stain). mag. $\mathbf{x 1 0 0 .}$ 


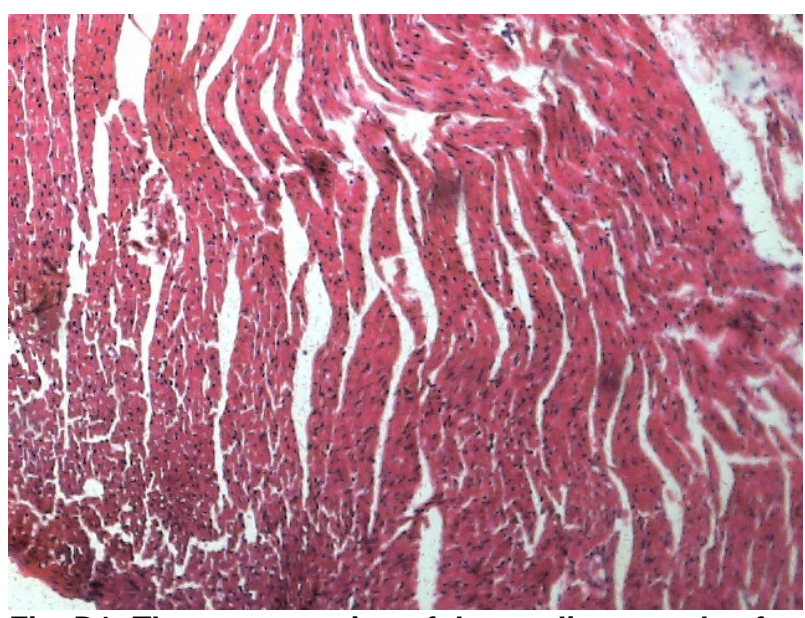

Fig. D1: The cross section of the cardiac muscle of the control group showing the branched network of muscle fibres (H and E stain). mag. X100.

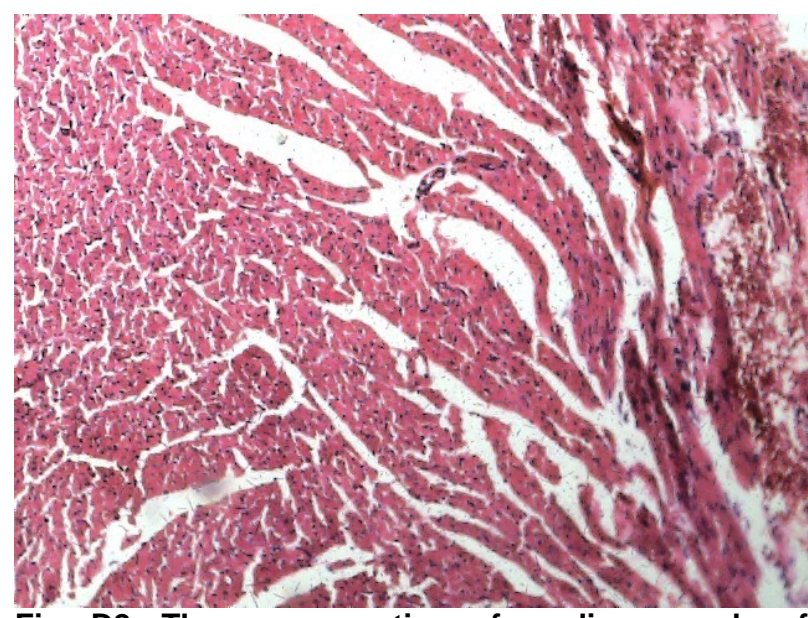

Fig. D2: The cross section of cardiac muscle of animal treated with $500 \mathrm{mg}$ of the drug. No abnormality was observed ( $H$ and $E$ stain). mag. $\mathrm{x} 100$.

\section{DISCUSSION}

Herbal medicines have received greater attention as alternative to clinical therapy in recent times leading to subsequent increase in their demand (Sushruta et al., 2006). In rural communities, the exclusive use of herbal drugs, prepared and dispensed by herbalists without formal training, for the treatment of diseases is still very common requiring that experimental screening method be established to ascertain the safety and efficacy of these herbal products as well as to establish their active components (Ogbonnia et al., 2008).

The microbial purity of the preparation showed that no growth was observed in the various diagnostic media used for bacterial and fungal organisms in the first $24 \mathrm{hr}$. In $72 \mathrm{hr}$ examination, Tryptone Soy Agar and MacConkey agar cultures showed $1 \times 10^{2}$ colonies of Bacilus subtilis respectively while in Cladosporum specie, $1 \times 10^{1}$ colonies on Sabouraud Dextrose Agar was observed on the $6^{\text {th }}$ and $7^{\text {th }}$ day of incubation and all were within acceptable official limits (Fontana et al., 2004).

The antimicrobial activities of the preparation revealed that there was no zone of inhibition on either the bacterial culture media or the fungal culture media thus signifying the absence of antimicrobial activity of the preparation against the microbial isolates used (Fisgin et al., 2009, Ganguly et al., 2001).

The acute toxicity study of the extract indicated no changes in the behavior and in the sensory nervous system responses in the animals. Also no adverse gastrointestinal effects were observed in the male

and female mice used in the experiment. All the mice that received $20.0 \mathrm{~g} / \mathrm{kg}$ dose of the extract died within $4 \mathrm{hr}$ while the animals that received $5.0 \mathrm{~g} / \mathrm{kg}$ dose survived beyond the 24 hours of observation. The median acute toxicity value $\left(\mathrm{LD}_{50}\right)$ of the extract was determined to be $7.2 \mathrm{~g} / \mathrm{kg}$ body weight. According to Ghosh (1984) and Klaasen et al., (1995) the extract could be classified as being slightly toxic, since the $\mathrm{LD}_{50}$ was found to lie between $5.0 \mathrm{~g}$ and $15.0 \mathrm{~g} / \mathrm{kg}$. The gram equivalence of the $L D_{50}$ in an average adult man would translate to $501.6 \mathrm{~g}$ dose of the drug. This is a very high value and makes the preparation relatively safe for use. The viscera of the dead animals did not show any macroscopic changes that could point to the cause of the death. However, since the animals did not convulse before dying, it postulated that the extract did not kill the mice by some action on the nervous system (Ogwal- Okeng et al., 2003)

The effects of the drug on the body weight variation of the tested animals was remarkable only on the groups that received higher doses of the polyherbal drug and no significant increase in weight was observed in the group that received low dose compared to the control (Table 2 and Fig.1). The decrease in the weights that occurred between day 5 and 15 in the groups treated with higher doses could be attributed to the initial suppression of the animals' appetite by the drug, and when this effect was overcome there was a dramatic gain in weight especially in the group treated with a dose of 250 $\mathrm{mg} / \mathrm{kg}$ bwt. 
There were no morphological changes in the colour of the various organs of the treated animals compared to the control but histological studies revealed that at the dose of $500 \mathrm{mg} / \mathrm{kg}$ bwt, the drug may have affected the sperm production rate in the testis as was evident in the scanty spermatocytes seen in the photomicrograph, but no abnormality was observed in the tissue morphology of the liver, kidney and heart. There were however, significant changes in the various organs weights especially in kidney, liver and brain in the animals that received the highest dose of the drug. The plasma protein level in all the treated animals showed no appreciable increase which suggested that the kidney did not compromise its function. However, the significant rise in the plasma creatinine concentration indicated implicit effect of the polyherbal drug on renal filtration mechanism.

The liver and heart release AST and ALT, and an elevation in their plasma concentrations indicate hepatic and cardiac damage (Mythilypriya et al., 2007; Wasan et al., 2001). Since the levels of these two enzymes showed no appreciable increase, it implied that drug had no harmful effect on the liver. This can also be confirmed by the histological study in which the hepatic tissue morphology showed no pathological changes. By the same token also, the extract may not have caused toxic effect on the heart tissue.

The polyherbal drug led to decrease in triglyceride (TG) level which suggested the presence of hypolipidemic agent. The increase in HDL-cholesterol levels (antiatherogenic agent) observed in all the treated animals

Table 5: White blood cells differential for control and the rats treated for $\mathbf{3 0}$ days with the polyherbal preparation

\begin{tabular}{|l|l|l|l|l|}
\hline \multirow{2}{*}{ Parameter } & DOSE mg kg & \multicolumn{5}{l|}{ body weight } & 250 & 500 \\
\cline { 2 - 5 } & Control & 100 & $70.1 \pm 1.9^{*}$ & $73.1 \pm 2.6^{*}$ \\
\hline Lymphocyte (\%) & $57.8 \pm 8.3$ & $71.6 \pm 2.4^{*}$ & $39.8 \pm 0.9^{*}$ & $36.0 \pm 5.6^{*}$ \\
Neutrophil (\%) & $25.2 \pm 2.9$ & $26.0 \pm 2.9$ & $3.0 \pm 0.2$ & $3.3 \pm 0.3$ \\
Monocytes (\%) & $2.0 \pm 0.6$ & $1.3 \pm 0.3$ & $780.3 \pm 10.1$ & $818.7 \pm 8.6^{*}$ \\
Platelet (\%) & $650.3 \pm 8.9$ & $830.7 \pm 5.8$ & \\
\hline
\end{tabular}

Mean \pm sem, $(n=5){ }^{*} \mathrm{p}<0.05$ vs. control group

Table 6: Haematological values of control and treatment rats with the phytomedicine for $\mathbf{3 0}$ days in subchronic study

\begin{tabular}{|c|c|c|c|c|}
\hline \multirow{2}{*}{ Parameter } & \multicolumn{4}{|c|}{ DOSE $\mathrm{mg} \mathrm{kg}^{-1}$ body weight } \\
\hline & Control & 100 & 250 & 500 \\
\hline $\mathrm{RBC} \times 10^{6}$ & $4.5 \pm 0.4$ & $6.0 \pm 0.2^{*}$ & $5.9 \pm 0.3^{*}$ & $6.5 \pm 0.2^{*}$ \\
\hline $\mathrm{Hb}(\mathrm{g} / \mathrm{dl})$ & $10.8 \pm 0.2$ & $11.7 \pm 0.4^{*}$ & $12.6 \pm 0.8^{*}$ & $14.3 \pm 1.3^{*}$ \\
\hline PCV (\%) & $30.6 \pm 1.4$ & $40.4 \pm 0.5^{*}$ & $41.0 \pm 1.1^{*}$ & $43.7 \pm 0.5^{\star}$ \\
\hline WBC $\times 10^{3}$ & $3.7 \pm 0.5$ & $3.8 \pm 0.7$ & $4.0 \pm 0.1$ & $5.1 \pm 0.6^{*}$ \\
\hline $\mathrm{MCV}(\mathrm{FL})$ & $59.9 \pm 1.4$ & $64.5 \pm 2.5^{*}$ & $62.3 \pm 2.2$ & $65.2 \pm 2.3^{*}$ \\
\hline $\mathrm{MCH}(\mathrm{pg})$ & $16.3 \pm 0.3$ & $17.2 \pm 0.2$ & $17.5 \pm 0.4$ & $17.4 \pm 0.6$ \\
\hline $\mathrm{MCHC}(\mathrm{g} / \mathrm{dl})$ & $30.1 \pm 2.2$ & $28.5 \pm 0.9$ & $29.0 \pm 1.1$ & $28.7 \pm 0.7$ \\
\hline
\end{tabular}

Mean \pm SEM $(n=5),{ }^{*} p<0.05 ;{ }^{* *} p<0.01$ vs. control group. Control group received $0.5 \mathrm{~mL}$ normal saline solution. equally suggested the presence of cardiovascular risk reducing factors known to contribute to the death of diabetic subjects (Crook, 2006).

The observed significant $(p \leq 0.05)$ increase in the haemoglobin levels in all the treated groups might be due to increase in the absorption of iron. The RBC population with values below the reference range can be termed "hypochromic". Low MCHC is associated with iron deficiency anemia where microcytic, hypochromic red cells are produced as a result of lack of iron to support haemoglobin synthesis. In this study however, there was no significant change in $\mathrm{MCHC}$ in the treated animals compared to the control. There were also no significant changes in MCV thus signifying that the polyherbal medicine did not regenerative anemia.

\section{CONCLUSION}

The herbal preparation though a non sterile aqueous microbiologically safe for human consumption.

The high $\mathrm{LD}_{50}$ value $(7.165 . / \mathrm{kg})$ obtained was a clear indication that the polyherbal preparation could be safe for use. It also exhibited hypolipidemic activity and good reducing effects on cardiovascular factors. The study revealed that the drug at doses investigated did not provoke toxic effects to the animals' liver, heart and kidney at high dose, but could have some effects on the male testes. Therefore there is the need to exercise caution in the use of Leon Bitters preparation for long term treatment of diseases as it might affect sperm count leading to decrease in productivity. 
Table 7: Weight variation of organs of the control and rats treated with phytomedicine doses in the subchronic study

\begin{tabular}{|l|l|l|l|l|}
\hline \multirow{2}{*}{ Parameter } & \multicolumn{5}{|l|}{ DOSE mg kg ${ }^{-1}$ body weight } & 250 & 500 \\
\cline { 2 - 5 } & Control & 100 & $2.4 \pm 0.2$ & $2.5 \pm 0.1$ \\
\hline Testes & $2.6 \pm 0.3$ & $2.2 \pm 0.5$ & $0.4 \pm 0.1$ & $0.5 \pm 0.1$ \\
Heart & $0.4 \pm 0.1$ & $0.4 \pm 0.1$ & $2.2 \pm 0.2$ & $2.6 \pm 0.2^{*}$ \\
lungs & $1.8 \pm 0.5$ & $2.1 \pm 0.3$ & $6.0 \pm 0.4$ & $6.1 \pm 0.6$ \\
liver & $5.6 \pm 0.3$ & $5.9 \pm 0.3$ & $1.6 \pm 0.1$ & $1.9 \pm 0.1^{*}$ \\
kidney & $1.3 \pm 0.1$ & $1.4 \pm 0.1$ & \\
\hline
\end{tabular}

Mean \pm SEM, $(n=5),{ }^{*} p<0.05 ; \quad{ }^{* *} p<0.01$ vs. control group. Control group received $2 \%$ Tween 80 solution

\section{REFERENCES}

Bandaranayake M. W (2006). Modern Phytomedicine. In: Turning Medicinal Plants into Drugs. Ahmad, I., Aqil F. and Owais M. (Editors.). Wiley $-\mathrm{VCH}$ Verlag $\mathrm{GmbH}$ \& Co. KGaA, Weinheim ISBN: 3-527-31530-6.

Bürger C., Fischer D. R., Cordenunzzi D. A., Batschauer de Borba A. P., ,Filho V. C and Soares dos Santos A. R (2005). Acute and subacute toxicity of the hydroalcoholic extract from Wedelia paludosa (Acmela brasilinsis) (Asteraceae) in mice. J Pharm Sci (www.cspsCanada.org) 8(2): 370-373.

Crook M. A (2006). Clinical Chemistry and Metabolic Medicine. $7^{\text {th }}$ Edition. Hodder Arnold, London: pp 426.

Ekaidem I. S., Akpanabiatu M. I., Uboh F. E and Eka O. $\mathrm{U}(2006)$. Vitamin b12 supplementation: effects on some biochemical and haematological indices of rats on phenytoin administration. Biokemistri 18(1): 31- 37

Fisgin T. N., Cayci T. Y., Coban Y. A., Ozatti D., Tanyel E., Durupinar B and Tulek N (2009). Antimicrobial activity of plant extract Ankaferd Blood Stopper. Fitoterapia, 80:48-50.

Fontana R., Mendes M. A., de Souza B. M., Konno K and Cesar L. M. N (2004). Jelleines, a family of antimicrobial peptides from the royal jelly of honey bees (Apis mellifera) peptides 25:919-928.

Ganguly, R., Mishra P and Sharma A (2001). Sensitivity of Salmonella Typhi isolated from patient in Roorkee to antibiotics and two Unani drugs. Indian J Microbiol, 41: $211-213$

Ghosh M.N (1984). Fundamentals of Experimental Pharmacology, $2^{\text {nd }}$ Edition. Scientific Book Agency, Calcutta; 154-157.

Hussain A and Eshrat H. M (2002). Hypoglycaemic, hypolipidemic and antioxidant properties of combination of Curcumin from Curcuma longa, Linn and partially purified product from Abroma augusta, Linn. in streptozotocin induced diabetes. Indian J Clinic Biochem 17(2): 33- 43.

Joshi C. S., Priya E. S and Venkataraman S (2007). Acute and subacute studies on the polyherbal antidiabetic formulation Diakyur in experimental animal model. J Health Sci 53(2): 245-249.
Klaasen C. D., Amdur M. O and Doull J (1995). Casarett and Doull's Toxicology: The basic science of poison. $8^{\text {th }}$ Edition. Mc Graw Hill, USA, 13-33.

Mythilypriya R., Shanthi P and Sachdanandam P (2007). Oral acute and subacute toxicity studies with Kalpaamruthaa, a modified indigenous preparation, on rats. J Health Sci 53(4): 351-358.

National Committee for Clinical Laboratory Standards (NCCLS) (1997). Methods for dilution antimicrobial susceptibility tests for bacteria that grow aerobically. 4th Edition. Approved standard M7-A4, 17, No. 2, Villanova PA.

Odukoya O. A., Inya-Agha S. I., Segun F. I, Sofidiya M. O and Ilori O. O (2007). Antioxidant activity of selected Nigerian green leafy vegetables. Am J Food Technol 2(3):169-175.

Ogbonnia S. O., Odimegwu J. I and Enwuru V. N (2008). Evaluation of hypoglycaemic and hypolipidaemic effects of aqueous ethanolic extracts of Treculia africana Decne and Bryophyllum pinnatum Lam. and their mixture on streptozotocin (STZ)-induced diabetic rats. Afr J Biotechnol. 7(15):2535-2539.

Ogbonnia S. O., Nkemehule F. E., Anyika E. N (2009). Evaluation of acute and subchronic toxicity of Stachytarpheta angustifolia (Mill) Vahl (Fam. Verbanaceae) extract in animals. J Biotechnol. 8(9): 1793-1799

Ogbonnia S., Adekunle., A. A., Bosa M. K and Enwuru V. N (2008). Evaluation of acute and subacute toxicity of Alstonia congensis Engler (Apocynaceae) bark and Xylopia aethiopica (Dunal) A. Rich (Annonaceae) fruits mixtures used in the treatment of diabetes. Afr $\mathrm{J}$ Biotechnol 7(6):701 -705.

Ogwal-Okeng W. J., Obua C and Anokbonggo W. W (2003). Acute toxicity effects of the methanolic extract of Fagara zanthoxyloides (Lam.) root-bark. Afr Health Sci 3(3): 124-126.

Pieme C. A., Penlap V. N., Nkegoum B., Taziebou C. L., Tekwu E. M., Etoa F. X and Ngongang J (2006). Evaluation of acute and subacute toxicities of aqueous ethanolic extract of leaves of (L) Roxb (Ceasalpiniaceae). Afr J Biotechnol 5, 3: 283- 289 
Agric. Biol. J. N. Am., 2010, 1(3): 366-376

Raghavendra M. P., Satish S and Raveesha K. A (2006). In vitro evaluation of anti-bacterial spectrum and phytochemical analysis of Acacia nilotica. J Agric Technol 2(1): $77-88$.

Rickert K., Martinez R. R and Martinez T. T (1999). Pharmacist Knowledge of Common Herbal Preparations. Proc. West. Pharmacol.Soc.42: 1-2.

Shah Ayub M. A., Garg S. K and Garg K. M (1997). Subacute toxicity studies on Pendimethalin in rats. Indian J Pharmacol. 29:322-324.

Sushruta K., Satyanarayana S., Srinivas N and Sekhar R. J (2006). Evaluation of the blood-glucose reducing effects of aqueous extracts of the selected
Umbellifereous fruits used in culinary practice. Trop $\mathrm{J}$ Pharmaceutical Res 5(2): 613- 617.

Tédong L., Dzeufiet P. D. D., Dimo T., Asongalem E. A., Sokeng S. N., Flejou J. F., Callard P and Kamtchouing P (2007). Acute and Subchronic toxicity of Anacardium occidentale Linn (Anacardiaceae) leaves hexane extract in mice. Afr $\mathrm{Jl}$ of Traditional and Alternative medicine 4(2): 140-147.

Wasan K. M., NajafiS Wong J and Kwong M (2001). Assessing plasma lipid levels, body weight, and hepatic and renal toxicity following chronic oral administration of a water soluble phytostanol compound FM-VP4, to gerbils. J Pharmaceutical Science (www.ualberta.ca/ csps) 4(3): 228-234. 